UDC 336.71:338.246.025

DOI: https://doi.org/10.37320/2415-3583/9.24

\author{
Kryshtal Halyna \\ $\mathrm{PhD}$ of Economic Sciences, \\ Interregional Academy of Personnel Management
}

Kapeliushna Tetiana

$\mathrm{PhD}$ of Economic Sciences,

State University of Telecommunications

\title{
SYNERGY OF THE BANKING AND SOCIO-ECONOMIC SECTORS UNDER THE INFLUENCE OF THE STATE REGULATOR
}

The article examines the factors that influence the relationship between the banking and socio-economic sectors, which testifies to their close relationship: the capabilities and potential of one sector increase as the other sector develops. The issues of sector synergy in the system of interaction between the bank and the state regulator, the banking and economic sector and the banking and social sector, both in theoretical, methodological and practical aspects, remain insufficiently developed. Banking entities should give the opportunity to use all opportunities to maximize profits without restriction in a period of economic growth, which will provide enough painless support to businesses in order to retain and develop full-fledged, strong partners in the future. The implementation of the principle should be temporary, and the costs of the banking sector can be offset by economic growth.

Key words: state regulator, banking sector, synergy, socio-economic sector, resources.

Introduction. The complex combination and interplay of internal and external factors give the synergies of banking and socio-economic sectors the contradictory character, which is exacerbated at the current stage of economic development. The most common internal factors of synergy between the banking and socio-economic sectors are risks, which account for $40 \%$ of the value of banking services. Regardless of the types of risks, accounting for them in the structure of bank interest rates, as a rule, leads to an increase in rates, which affects the limited ability to initiate a synergy or reduce its intensity and quality.

Analysis of recent research and publications. Today, scientists in the field of state regulation and banking, such as Adamovskaya V.S., Didkivska L.I., Golovko L.S., Minenko V.L., Chugunov I.I., Pavelko A.V. consider issues of state regulation in their works. However, it is worth noting that there are practically no studies on the synergy of state regulation of banking and socio-economic activity.

The purpose of the article is to identify the synergy of state regulation of banking and socio-economic activities and to organize an effective synergy mechanism.

Outline of the main research material. Some banks are inclined to pursue an aggressive investment policy, taking on high risks that result in increased arrears and a decline in the quality of their banking assets. Having gained negative experience, banks go either by reducing the practice of unnecessary risk financing or by offsetting risks by increasing the cost of servicing. In other words, attempting to minimize risks by adjusting the interest rate of one bank may restrict access to resources and in many others, which focus on average market interest rates.
The mortgage collateral valuation techniques used by banks, based on the banks' desire to take into account the negative experience and to be re-insured for a certain period of time even in the case of low risk, further increase the cost of servicing.

In our opinion, in the current practice of synergy of the banking and socio-economic sectors the effect of such a factor as the policy of attracting banking resources, as the formation and distribution of resources occurs through different channels, the priority of which has changed in recent years, does not lose its importance. In particular, statistics for 2019 show that the main source of banks' resource base are deposits of the society, interbank loans and credits of the National Bank. This structure demonstrates the shift of emphasis towards internal deposit sources in order to give the resource base stability and independence from external sources. Therefore, in spite of some post-crisis reductions in the rates on current contributions, the principles of money transfer and the operation of state deposit insurance systems determine the lion's share of this source in the structure of banking resources [1].

Significant transformation of bank liquidity flows occurred due to instability in the interbank lending market, as a result of crisis phenomena, significantly reducing banks' resource potential and limiting the activity of their synergy with economic sector enterprises. At the same time, loans in the interbank credit market are still significant because of the multiplier effect through the influence of banks' resource base on the growth of production, increase in output and services [2].

Due to the need to counterbalance the effects of the crisis and the problems with bank liquidity, NBU 
refinancing loans, previously used solely to influence the cash flow, have become more widely used. Thus, in the world practice there are cases when central banks with the help of refinancing instruments began to stimulate the interaction of the banking and economic sectors with the aim of mitigating the negative impact of structural imbalances of reproduction through the implementation of operations related to guarantees, lending to priority industries, using differentiated interest rates $[3 ; 5]$.

The so-called "mirror" effect has such a factor as the level of development of information and technological potential of the sectors. On the one hand, this factor has a positive effect on the state of banks and enterprises, since the introduction of innovation reduces the cost of products and services, promotes the modernization of production facilities and increases the investment activity and attractiveness of each other's entities $[4 ; 6]$; banks generate growth in financial innovations oriented towards more adequate and diversified satisfaction of the needs of economic sector enterprises (new types of investment deposits are emerging, securitization of bank assets, credit and interest rate derivatives, indexed instruments, etc. are used) [5]; on the other hand, rapid development of information and financial technologies contributes to the weakening of links between sectors by increasing speculative banking operations that are detached from the needs of the socio-economic sector.

The current trends of synergy of the banking and socio-economic sectors, accompanied by instability of the world economic and financial situation, show that in relation to internal factors, external factors are acting directly, which are related to the changing state of the economy, volatility of the world financial and raw materials markets, specifics and vector of economic policy and norms of state regulation.

The government's economic policy in most market economy countries is geared to supporting sustainable economic growth by stimulating investment activity that integrates scientific and technological processes and economic, social, and political aspects. Thus, the goal of economic development strategies implemented in other countries is to diversify the economy, including through the intensive use of modern technologies and the rational redirection of domestic sources of financing to priority industries $[7 ; 8]$.

Following the example of the most developed countries, development banks have been set up to play an important role in the development of economic infrastructure and priority sectors of the economy, filling the existing shortage of resources in the banking sector. At the same time, one of the directions of intensification of investment activity by the state is the use of funds accumulated in pension, insurance and sovereign national funds, which allows to partially resolve the question of dependence of the banking sector on external long-term sources.

Therefore, in our opinion, infrastructure development is a factor that stimulates the interaction of the banking and socio-economic sectors. Those who have developed infrastructure institutes include: credit bureaus that provide information transparency, mitigate risks and prompt service; insurance institutions that support the sustainability of the synergy process; collection agencies and funds of problem assets, the activity of which is focused on solving problems with accumulated overdue debt; the independent valuation companies providing liquidity assessment of mortgage property, etc.

The balanced regional policy of the state, which combines the support of both the regional banking sector and the direct support of enterprises of priority sectors of the economy and industry, is able to act as a factor that stimulates the successful interaction of the sectors. However, such advantages of regional banks are maneuverability in transactions, possession of information about the real state of affairs in industries and regions, the ability to meet the existing needs flexibly and adequately, in the current conditions are overcome by such problems as significant territorial remoteness, unprofitable business infrastructure, which narrows the accessibility of banking services to the socio-economic sector.

In the years of economic prosperity, the banking sector is less and less thinking about risk, increasing the volume of its loan portfolio, including attracting more favorable external borrowing for them. In turn, economic sector enterprises, with significant external debt and losing price competitiveness as a result of the speculative boom and the appreciation of the national currency, are experiencing a deterioration in financial results, which gradually leads to a slowdown in production growth and an increase in defaults. At the same time, under the combined burden of increasing the interest rate and non-repayment of loans, the condition of the banking sector deteriorates as well, since over-speculated mortgage objects due to the changed conditions can no longer cover the volume of previously issued loans.

Assessment of the factors, which affect the relationship between the banking and socio-economic sectors, indicates their close relationship: the capabilities and potential of one sector increase as the other sector develops. Systematicity as a property of the process of synergy of the banking and socio-economic sectors is caused by: firstly, the genesis of the definitions of the "banking sector" and "socio-economic sector", which represent the integrity, which consists of many interdependent elements; secondly, the systemic nature is manifested in the embeddedness of the activities of the subjects of both sectors in the macroeconomic system, which reflects the effects of their synergy and, at the same time, the inevitabil- 
ity of the reciprocal changes in the situation of the subjects of the sectors; thirdly, the process of synergy of the banking and socio-economic sectors is a component of the system structure, which has its own natural behavior, self-development, self-government, self-organization, adaptation on the basis of mutual synergy of elements and functions [7].

The banking sector, while having access to information on the status of socio-economic entities on the basis of servicing their accounts, most often uses degrading tools that are contrary to the interests of the latter. The property of regulation, due to the fact that the results of the synergy of the subjects of the sectors or the lack thereof, affect the course and quality of socio-economic development, which makes interaction of the object of state regulation. Using administrative levers, methods and instruments of economic policy, the state adjusts the synergy process, defines its perspective directions of development and "points of growth", stimulating the prevailing direction of resources in them.

The complexity of the synergy process of the banking and socio-economic sectors is that its financial, economic, structural, functional and technological and other components must be realized through the prism of taking into account the views and interests of the parties and the compromise on which the sustainability of the process sectors depends, as it is the imperfection of management systems that has been identified as the main cause of the "cooling" of relations between sectors in times of global crisis. Manageability is the set of planning, organization and control actions taken by the synergies that are forced to take into account not only the asymmetrically directed interests and goals of the counterparties, but also their permanent tendency to change in the external environment; it is an important characteristic of the synergy process.

At the initial stage of the initiation and organization of the synergy process of the banking and socioeconomic sectors, characterized by the assessment of the potential counterparty and deciding on the feasibility of synergy, the principle of mutual justification, the implementation of which is focused on overcoming the existing asymmetry of information between the entities. Indicative, in this case, is a situation where banks, in an effort to improve their performance in times of crisis, may artificially overstate the borrower's financial condition to reduce the amount of reserves created, and, in the assessment of credit applications, on the contrary, to lower. Such inconsistency in the estimates gives unreliable results and affects the degree of validity of the decision.

The practice of using external credit ratings, as recommended by the Basel Committee (Basel II and III), shows that current rating systems are often isolated and not integrated into the synergy risk management process, which threatens not only the risk management and risk reduction, but also the synergy itself. The deterioration in the quality of banks' assets and the status of economic sector entities in the post-crisis period clearly demonstrates the importance of this principle and requires the improvement of valuation practices as an important institutional component of the development of sector synergies.

It is the long-term nature of synergies based on the principle of partnership between the actors of the sectors that has the potential to provide a multiplicative impetus for growth of investment activity and enhancement of inter-sectoral resource flows. From the point of view of supporting the process of synergy of the banking and socio-economic sectors by the state regulator and ensuring its orientation towards achieving the expected results, in our view, the principle of coordination of banks by the National Bank of Ukraine, implementation of which allows to avoid contradictions and reduce transaction costs on the basis of aligning and adjusting the strategies of the entities of the sector according to the changed conditions of their functioning.

Despite the fact that the misconduct of the banking and the socio-economic sectors has always been one of the problems limiting their interaction, it has been particularly talked about today when it became clear that the risk of the impact of external destructive factors in the context of globalization on financial markets are so large that it is necessary, first of all, to achieve internal stability and stability of relations between actors of strategically important sectors of the economy and society.

Therefore, in our opinion, it is not advisable to speak of corporate social responsibility of entities separately, since it does not produce results due to the split of positions: conditions and obligations may be fixed in documents of sector entities, but in the process of synergy, they may not work. Considering that no regulator other than the interacting entities themselves is able to best monitor their compliance, it should be a matter of implementing the principle of mutual responsibility, which envisages the fulfillment of the commitments undertaken by the entities, the development of stable communications and the confidence between them.

Current trends in the decline in the quality of banking sector assets against the backdrop of slowing economic growth, the need to divert bank resources to create reserves, the problems of banks' liquidity and capital adequacy predetermine the active position of financial regulators in the implementation of the countercyclical principle, which involves the implementation of two scenarios of growth: additional reserves in case of stressful situations and shocks, attraction of mainly internal sources of funding, perfection of the risk management system; at the stage of crisis: implementation of conservative policy of ser- 
vicing the economic sector, characterized by the use of previously accumulated potential [3].

However, according to some academics and practitioners in the banking sector, the introduction of a counter-cyclical approach by regulators can significantly limit the amount of resources that could be channeled into the socio-economic sector as the economy grows. In our view, these concerns are fully justified for the following reasons: firstly, the change in the size of reserves created by banks, regardless of the stage of the economic cycle, leads to a restriction of bank investments in the development of the economic sector, which in the conditions of economic development will weaken the interaction of sectors against the background of the need for implementation of the innovative strategies; secondly, the implementation of the countercyclical approach of regulators is based on the recommendations of international financial institutions, credit agencies and Basel agreements that do not take into account the peculiarities of the national economy of developing countries, the current state, potential and capabilities of the economic, banking and social sectors other than the world financial centers' capacities and capabilities; thirdly, the need to implement the countercyclical principle should not come from regulators, but be embedded in the synergy mechanism of the banking and socio-economic sectors.

In this regard, the principle of counter-cyclicality means exclusively the behavior of the banking and socio-economic sectors, which sometimes goes against the true interests of each party in the interests of maintaining the stability of relations and cooperation in the conditions of unfavorable period of economic development.

Conclusions. Banking entities should be given the opportunity to use all the opportunities to maximize profits without restriction in a period of economic growth, which will provide enough painless support to businesses in order to retain and develop full-fledged, strong partners in the future. The implementation of the principle should be temporary, and the costs of the banking sector can be offset by economic growth, as the parties can agree in advance and consolidate their obligations in the relevant treaties.

In the period before the formation of stable informal institutions, it is advisable to consolidate the principle in the legislative order. It should be noted that the implementation of the set of principles presented is aimed at eliminating the inevitable contradictions, conflicts and disputes between the entities of the banking and socio-economic sectors. Harmonization of the conditions, search for solutions, mutual consideration of interests, exchange of ideas and intentions, joint search for satisfaction of the needs of the interacting parties inevitably leads to a compromise adjustment of the goals, self-esteem, and behavior of the interacting entities and changes of their initial state, gradually forming the corresponding composition of the institutional background, formal (reflective) institutions for assessing, regulating and allocating resources and risks, and informal (ethical) norms and traditions of relationships between actors in the sectors.

\section{References:}

1. Adamovskaya V.S. (2017) Mekhani`zm derzhavnogo regulyuvannya ekonomi`ki ta vibi`r napryamu ekonomi’chnoyi poli tiki v suchasnikh umovakh gospodaryuvannya. [The mechanism of state regulation of the economy and the choice of direction of economic policy in modern conditions of management]. Public Administration: Improvement and Development. no. 4, pp. 118-120.

2. Chugunov I.Y., Pavelko A.V., Kaneva T.V. (2015) Derzhavne fi'nansove regulyuvannya ekonomi 'chnikh peretvoren`. [Monografi ya]. [State financial regulation of economic transformations]. Kiev: Kyiv National University of Trade and Economics. (in Ukrainian)

3. Deidda L. (2005) Non-linearity between Finance and Growth. Economics Letters. Vol.74. no. 3. pp. 339-345.

4. Didkivska L.I., Golovko L.S. (2008) Derzhavne regulyuvannya ekonomi ki. [State regulation of the economy]. Knowledge-Press. pp. 205-208.

5. Minenko V.L. (2013) Teoretiko-metodologi`chni zasadi uzgodzhennya vzayemodi yi mekhani`zmi`v derzhavnogo regulyuvannya i` samoregulyuvannya rinku praczi'. [Theoretical and methodological principles of harmonization of interaction of mechanisms of state regulation and self-regulation of the labor market]. Kyiv: Theory and Practice of Public Administration. Vol. 3 (42). pp. 78-83. (in Ukrainian)

6. Mocherniy S.V. (2009) Ekonomi chna teori'ya. [Economic theory]. Kiev: Academy of Sciences. P. 312-326. (in Ukrainian)

7. Osborne D. (1992) Reinventing government: how the entrepreneurial spirit is transforming the public sector. Reading, Mass. Addison-Wesley Pub. 405 p.

8. O'Toole L. (1997) The Implications for Democracy in a Networked Bureaucratic World. Journal of Public Administration Research and Theory. Vol. 7. pp. 443-459.

\section{Список використаних джерел:}

1. Адамовська В. С. Механізм державного регулювання економіки та вибір напряму економічної політики в сучасних умовах господарювання. Київ: Державне управління: удосконалення та розвиток, 2017. № 4. C. 118-120.

2. Чугунов І.Я., Павелко А.В., Канєва Т.В. Державне фінансове регулювання економічних перетворень. [Монографія]. Київ: Київський національний торговельно-економічний університет, 2015. 376 с.

3. Deidda L. Non-linearity between Finance and Growth. Economics Letters, 2005. V.74. № 3. P. 339-345.

4. Дідківська Л. І., Головко Л. С. Державне регулювання економіки. Київ: Знання-Прес, 2008. С. 205-208. 
5. Міненко В. Л. Теоретико-методологічні засади узгодження взаємодії механізмів державного регулювання і саморегулювання ринку праці. Київ: Теорія та практика державного управління, 2013. Вип. 3 (42). С. 78-83.

6. Мочерний С. В. Економічна теорія. Київ: ВЦ «Академія», 2009. С. 312-326.

7. Osborne D. Reinventing government: how the entrepreneurial spirit is transforming the public sector. Reading, Mass. Addison-Wesley Pub, 1992. 405 p.

8. O'Toole L. The Implications for Democracy in a Networked Bureaucratic World. Journal of Public Administration Research and Theory, 1997. Vol. 7. P. 443-459.

Кришталь Г.О., Капелюшна Т.В. Державний університет телекомунікацій

\section{СИНЕРГІЯ БАНКІВСЬКОГО ТА СОЦІО-ЕКОНОМІЧНОГО СЕКТОРІВ ПІД ВПЛИВОМ ДЕРЖАВНОГО РЕГУЛЯТОРА}

Практичне виявлення синергетичного ефекту в результаті взаємодї елементів (підсистем) системи відбувається у вигляді появи нових властивостей, функиій або механізмів функиіонування новоствореної інтегрованої структури. Ось чому поява нових властивостей та якостей дає змогу досягти набагато більшого ефекту на спільну дію підсистем, ніж проста механічна сума результатів їх самостійної роботи. Вивчення синергї як філософської категорії призвело до сприйняття багатьма авторами процесу, динамічна зміна стану (або рух складових його елементів) визначає його внутрішню иілісність $і$ стимулює загальний розвиток (причина існування системи може бути власним наслідком). Питання синергії сектору в системі взаємодіі банку - державного регулятора, банківсько-економічного сектору та банківсько-сочіального сектору, як в теоретичному, так і методологічному та практичному аспектах, залишаються недостатньо розробленими. Мета статті - виявити синергію державного регулювання діяльності банківської та сочіально-економічноі сфери та організувати ефективний механізм синергї. Доведено, щзо довгостроковий характер синергії, заснований на приниипі партнерства між суб'єктами секторів, може забезпечити мультиплікативний поштовх для зростання інвестииійної активності та активізаиії міжгалузевих потоків ресурсів. 3 точки зору підтримки процесу синергї між банківським сектором та сочіально-економічною стороною державного регулятора та забезпечення його спрямованості на досягнення очікуваних результатів важливим є приниип координації банків НБУ, регулювання з боку якого дозволяє уникнути суперечності та зменшує трансакційні витрати на основі координачії та коригування підрозділів секторів відповідно до змінених умов їх роботи. Банківським суб'єктам господарювання слід надати можливість використовувати всі можливості для максимізаиї прибутку без обмежень у період економічного зростання, що надасть достатньо безболісної підтримки бізнесу з метою збереження та розвитку повноиінних, сильних партнерів у майбутньому. Реалізачія иього приниипу має бути тимчасовою, а витрати банківського сектора можуть бути компенсовані економічним зростанням, оскільки сторони можуть заздалегідь домовитись $і$ закріпити свої зобов'язання у відповідних договорах.

Ключові слова: державний регулятор, банківський сектор, синергія, сочіально-економічний сектор, ресурси.

JEL classification: E58. 